\title{
Descriptions of Neboissomina, new genus and 6 new species of Ecnomidae from Australia (Trichoptera)
}

\author{
DAVID I. CARTWRIGHT \\ 13 Brolga Crescent, Wandana Heights, Victoria 3216, Australia.E-mail: cartwright@hotkey.net.au
}

\begin{abstract}
Descriptions and keys are provided for males of 7 ecnomid caddisfly species, with 6 species new to science and to Australia. Females of 5 species are also described. These species are placed in the new genus, Neboissomina, new genus. The following new species are described: $N$. jardinei, $N$. kuranya, $N$. mida, $N$. persona, $N$. philsuteri, and $N$. riyala. A new combination is suggested for $N$. krokale (Neboiss, 1979). The new genus is erected based on unique characters in the male and female genitalia, wings and setal warts of the head. Neboissomina, new genus is endemic to northern and eastern Australia.
\end{abstract}

Key words: Caddisflies, ecnomid, taxonomy, keys, Insecta

\section{Introduction}

The adults of Ecnomus McLachlan, Daternomina Neboiss, Ecnomina Kimmins, Austrotinodes Schmid, Absensomina Cartwright and Wellsomina Cartwright have been revised (Cartwright 1990, 2008, 2009, 2010). With the first 4 of these genera, associated larvae were recognized as being critical in clarifying relationships. However, this is not the case with the latter 2 genera and the new one described here. Confirmed larvae of Neboissomina, new genus, have not been collected to date. Adults are not often collected in large numbers although some of the species are widespread.

The genitalia of Neboissomina males superficially seem most closely related to some Ecnomina, Daternomina and Austrotinodes species that have large fused, plate-like inferior appendages. Neboissomina males differ from other ecnomid genera by having a pair of long, dorso-ventrally flattened (depressed) processes (mesal processes of tergum X) ventro-basal to the superior appendages. The female genitalia, with a pair of relatively small lobes divided by a median notch on sternite VIII, differ from the genitalia of Ecnomina which have a single elongate lobe or process, and from those of Austrotinodes and Daternomina females which have a pair of relatively large lobes on sternite VIII. The wing venation is similar to that of Ecnomina, Austrotinodes and Daternomina in that the forewings have relatively long fork 2 and fork 3, each with short footstalks, and the hind wings each have fork 3 longer than its footstalk. Information from females and larvae may help resolve phylogenetic relationships among these genera. The description of this new genus and 6 new species in this paper takes the Australian ecnomid fauna to 7 genera and 123 species and the world ecnomid fauna to a relatively large total of at least 13 genera and 421 species.

Support for the reciprocal monophyly of the new genus and its closest relatives rests in the fact that among the 7 currently recognized ecnomid genera with species with fused male inferior appendages, each genus is probably monophyletic as indicated by characters discussed by Cartwright (2010) and by the fact that Neboissomina has the following probable synapomorphies: (a) female sternite VIII has a pair of small lobes separated by a median notch and (b) the male has a pair of long, dorso-ventrally flattened (depressed) mesal processes on tergum X. Further support comes from a molecular analysis of most ecnomid genera by Johanson and Espeland (2009), whose study confirmed that "Ecnomina" krokale belongs in a new genus and is phylogenetically distinct from both Ecnomina and Daternomina. 
Neboiss (1979) originally described Ecnomina krokale from Fraser Island, southeastern Queensland. Here, E. krokale is transferred to Neboissomina. Wells (1991) partly figured 7 undescribed species of Ecnomina in a key to Northern Territory (Alligator Rivers Region) Trichoptera of which 2, or possibly 3 are species of Neboissomina (Ecnomina spp F, H and A). Wells and Cartwright (1993) listed 6 undescribed species of Ecnomina amongst Trichoptera collected from Cape York Peninsula, north Queensland. These 6 species included 2 species of Neboissomina (as Ecnomina sp. n. B and Ecnomina sp. nr krokale). Walker et al. (1995) and Cartwright (1997) recorded Neboissomina persona (as Ecnomina sp. nov. PT-1591) from the Queensland Wet Tropics, northeastern Queensland.

In this report, nearly 300 male and female specimens of Neboissomina were examined and referred to 7 species. The species Neboissomina jardinei comprised the largest proportion of the Australian fauna with $71 \%$ of specimens, followed by $N$. persona with about 20\%. Four species are each known from fewer than 3 specimens.

The new genus Neboissomina is recorded from eastern Queensland (2 southeastern species, 3 northeastern species), and across northern Australia through the Northern Territory (1 species), and into northern Western Australia's Kimberley region (1 species).

In Australia, the relatively 'northern' (mainly Torresian) distribution of Neboissomina, Wellsomina and Absensomina, differs from that of the 'southern' and 'eastern' (mainly Bassian) distribution of Ecnomina, Daternomina and Austrotinodes. The widespread and abundant genus Ecnomus is also most common in northern (Torresian) Australia.

Size, body and wing colour can be useful characters, but are variable. Colour should be considered with caution since the colour often fades with time in alcohol. Depositories for specimens are abbreviated as follows: Museum Victoria, Melbourne (NMV) and Australian National Insect Collection, Canberra (ANIC). All specimens, including types, mentioned in the text are lodged in the NMV unless stated otherwise.

Species are most readily distinguished by genitalic features of both the males and females, often requiring clearing of the abdomen in potassium hydroxide. Females were paired somewhat tentatively with respective males on the basis of similarities in size and coloration, and on wing venation and locality. The distributions of some species of Neboissomina overlap and many of the females are very similar and hard to distinguish without clearing.

Specimens are identified by the notebook numbers of Dr. Arturs Neboiss (NMV), prefix PT-; or the author; prefix CT-. Terminology used generally follows that of Neboiss $(1977,1982)$ and Li and Morse (1997). Abbreviation of genitalic structures are indicated on selected figures for each genus and additionally where necessary. Typically, setae or spines are illustrated only on the right side of a symmetrical figure (as viewed) to enable a clearer presentation of the underlying structures. Length/ width measurements generally mean maximum length divided by maximum width.

\section{Key to genera of Australian (and south-west Pacific) Ecnomidae adults}

(after Flint 1973; Li and Morse 1997; Cartwright 2008, 2009, 2010)

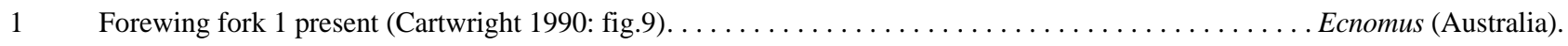

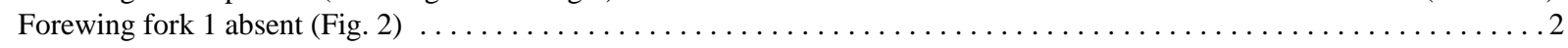

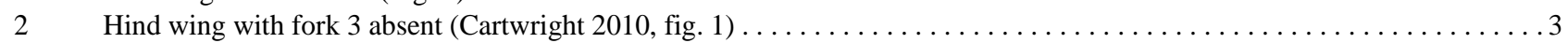

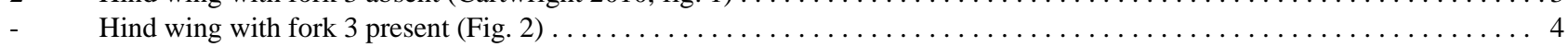

3 Forewing fork 2 with a short footstalk, footstalk about same length as crossvein $r$ - $m$, fork 3 sessile (Ward \& Schefter 2000, fig. 4); head dorsally with posterior occipital warts positioned longitudinally (Ward \& Schefter 2000, fig. 1) .............

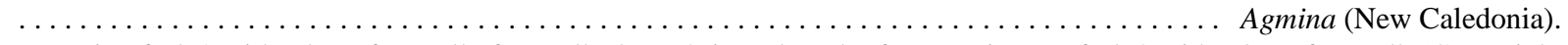
Forewing fork 2 with a long footstalk, footstalk about 4 times length of crossvein $r$ - $m$, fork 3 with a long footstalk (Cartwright 2010, fig. 1); head dorsally with posterior occipital warts positioned transversely (Cartwright 2010, fig. 2) $\ldots \ldots \ldots \ldots$

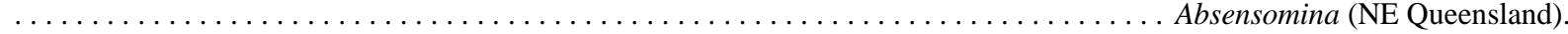
Forewing with both forks 2 and 3 relatively short and with long footstalks, and hind wing with fork 3 shorter than footstalk

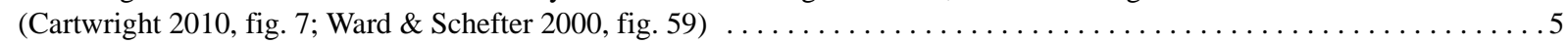
Forewing with both forks 2 and 3 relatively long and with short footstalks, and hind wing with fork 3 longer than footstalk

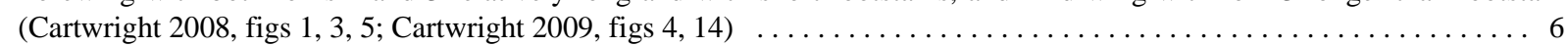

5 Hind wing fork 2 relatively short with long footstalk, footstalk about 3 times length of crossvein $r$ - $m$; humeral lobe present

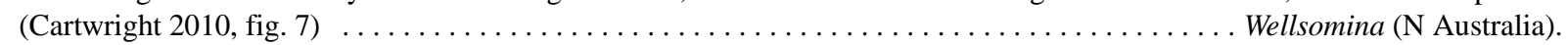
Hind wing fork 2 relatively long with short footstalk, footstalk about as long as crossvein $r$ - $m$; humeral lobe absent (Ward \&

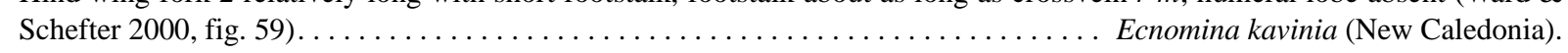

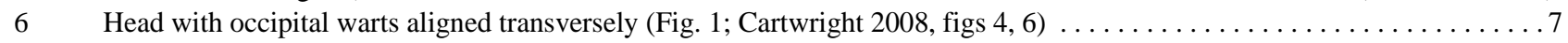


Head with occipital warts aligned longitudinally (Cartwright 2008, fig. 2; Cartwright 2009, fig. 15) . .........8 Female with pair of relatively small lobes or with no obvious lobes on sternite VIII (Figs 24-28); male tergum X with a pair of long, dorso-ventrally flattened mesal processes (Figs 3, 5) . . . . . . . . . . Neboissomina (N. and E. Australia). Female with a single elongate lobe or process (Cartwright 2008, figs 173-195; Neboiss 2003, fig. 16A); male tergum X without a pair of long, dorso-ventrally flattened mesal processes (Cartwright 2008, figs 63-65) ..................

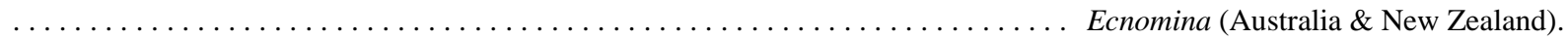

Forewing with cross veins $r-m$ and $m$ contiguous at fork 3 (Cartwright 2009, figs 4, 14); female usually with a pair of large irregular-shaped lobes or processes on sternite VIII (Cartwright 2009, figs 37-40); fore- and hind wings with fork 2 usually with footstalk, rarely sessile, forewing fork 2 without nygma (Cartwright 2009, figs 4, 14); scutellum with oval scutal wart (Cartwright 2009, fig. 15) . . . . . . . Austrotinodes [species from E Australia and South America (Chile, Argentina) only]. Forewing with cross veins $r-m$ and $m$ not contiguous at fork 3 (Cartwright 2008, fig. 1); female with pair of large rounded or 'tongue-shaped' lobes on sternite VIII (Cartwright 2008, figs 55-62; Neboiss 2003, fig. 16E); fore- and hind wings with fork 2 usually sessile, rarely with short footstalk, forewing fork 2 usually with nygma (Cartwright 2008, fig. 1); scutellum with heartshaped scutal wart (Cartwright 2008, fig. 2) . . . . . . . . . . . . . . . . . . . . Daternomina (S and E. Australia).

\section{Descriptions}

\section{Neboissomina, new genus}

Type species. Neboissomina jardinei, new species, by original designation.

Diagnosis. Male genitalia with inferior appendages, fused, forming a large ovoid or subquadrate plate; with a pair of long, dorso-ventrally flattened mesal processes of tergum X. Female genitalia typically with a pair of small lobes or occasionally without obvious lobes on sternite VIII. The forewings have both forks 2 and 3 long and with short footstalks, and the hind wings with fork 3 longer than the footstalk. Head with occipital warts aligned transversely.

Description. Adults small; length of each forewing: males 2.4-3.1 mm, females 2.7-3.1 mm; forewings narrow, each with length 3.3-4.0 times width; head dorsally with occipital warts aligned transversely, scutellum with heart-shaped scutal wart (Fig. 1). Wing venation: Each forewing with $R 1$ divided distally (sometimes reunited near wing margin), forks 2, 3, 4 and 5 present; fork 2 long, sessile, length of fork 2 ranges from 1.3-2.3 times length of fork 3; fork 2 nygma absent; fork 3 length 0.9-4.5 times length of footstalk, footstalk of fork 3 length 2.6-7.0 times length of cross-vein $m$, cross-veins $r-m$ and $m$ usually contiguous or nearly meeting at fork 3 ; fork 4 slightly shorter than fork 3; discoidal cell closed, length about 3 times width. Hind wings each with length $3.8-4.7$ times width, forks 2, 3 and 5 present, fork 2 footstalk length 2.0-5.0 times length of cross-vein $r-m$, discoidal cell length about 3 times width, 2 anal veins (Fig. 2). Male genitalia with superior appendages in dorsal view club shaped with slightly dilated apices; inferior appendages fused, forming a large, ovoid or subquadrate plate with pair of long, dorso-ventrally flattened (depressed) processes (mesal processes of tergum X) ventro-basal of superior appendages (Figs 323). Female genitalia typically with a pair of small lobes on sternite VIII, segment IX long, tapering distally, with several pairs of hairs; and segment X short, about half length of segment IX, with pair of cerci (Figs 24-28).

Etymology. Neboissomina- named after Dr Arturs Neboiss, for his great contributions to the study of Trichoptera in Australia, combined with part of generic name Ecnomina (Greek, "little outlaw"). The gender of Neboissomina is feminine.

Distribution. Neboissomina is a widespread northern and eastern Australian endemic genus, with 7 species recorded from eastern Queensland, the Northern Territory and northern Western Australia's Kimberley region.

\section{Key to males of species of Neboissomina}

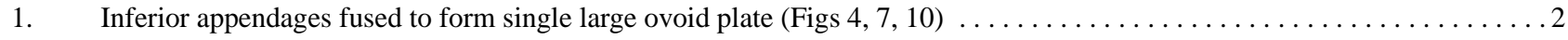
Inferior appendages fused to form single large sub-rectangular plate (Figs $13,16,19,22) \ldots \ldots \ldots \ldots$

2. Inferior appendages not tapered strongly in distal quarter to form single point, truncate distally (Fig. 4) NE-Qld ...........

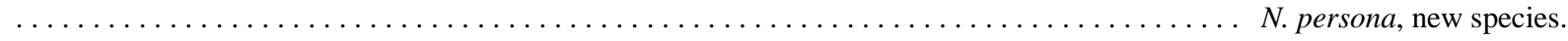
Inferior appendages tapered strongly in distal quarter to form single point, not truncate distally $($ Figs 7,10$) \ldots \ldots \ldots \ldots$

3. Inferior appendages with single meso-dorsal process visible subapically (Figs 6, 7); superior appendages not tapered in distal

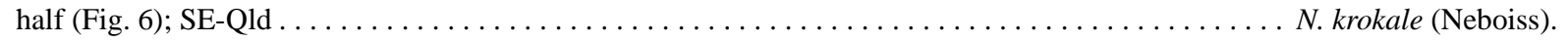
Inferior appendages without single meso-dorsal process, but with pair of lateral processes visible subapically (Figs 9, 10); superior appendages tapered in distal half (Fig. 9); NE-Qld $\ldots \ldots \ldots \ldots \ldots \ldots \ldots \ldots \ldots \ldots \ldots . . \ldots \ldots$ mida, new species. 
4. Superior appendages broadest near middle, not gradually tapered distally; inferior appendages in lateral view sub-quadrate,

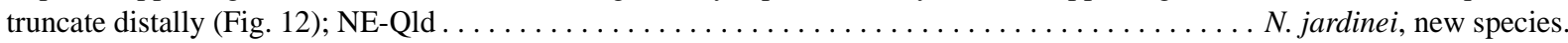
Superior appendages not broadest near middle, gradually tapered distally; inferior appendages in lateral view not sub-quadrate,

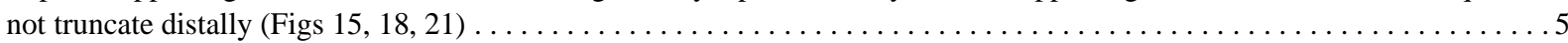

5. Inferior appendages in ventral view with single, small meso-distal rounded process (Fig. 16), in lateral view sub-triangular,

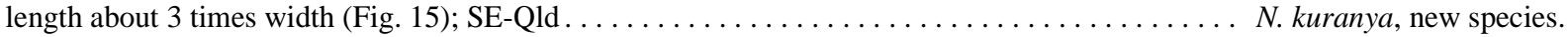
Inferior appendages in ventral view without single small meso-distal process (Figs 19, 22), in lateral view not sub-triangular,

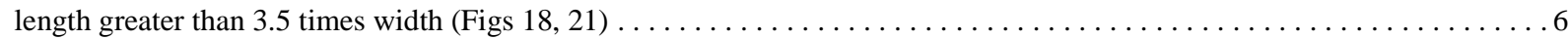

6. Inferior appendages in lateral view narrowed in distal $1 / 5$ th, dilated apically (Fig. 18); N-NT . . . . N. riyala, new species. Inferior appendages in lateral view, not narrowed in distal 1/5th, not dilated apically (Fig. 21); N-WA ............

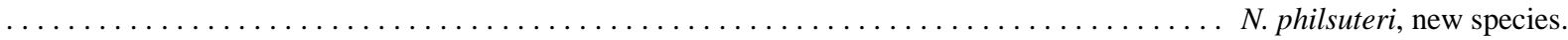

\section{Neboissomina persona sp. nov.}

Figs 3-5, 24

Diagnosis. Neboissomina persona is most similar to, N. krokale and N. mida, in the inferior appendages which are fused into large, ovoid plates, however in $N$. persona the apex is truncate distally separating it from the 2 other species where the apices are tapered into a single point.

Description. Head, body, and wings light brown, abdomen paler ventrally; wings similar to those of $N$. jardinei, new species (Fig. 2); length of each forewing: male 2.6-3.5 mm, female 2.6-3.4 mm, about 3.3 times width; length of each hind wing 3.4-3.7 times width. Wing venation: Each forewing with forks 2, 3, 4 and 5 present; fork 2 length 1.4-1.8 times length of fork 3; fork 3 with variable footstalk, fork 3 length 1.3-4.5 times length of footstalk, footstalk fork 3 length 1.1-2.6 times length of cross-vein $m$; cross-veins $r-m$ and $m$ nearly contiguous at fork $3, r-m$ and $m$ separated by $0.4-1.0$ times length of cross-vein $m$; fork 5 length about 1.7 times length of fork 4 . Hind wings each with forks 2,3 and 5 present; footstalk of fork 2 length $0.0-2.4$ times length of cross-vein $r-m$, fork 2 length 1.2-1.5 times length of fork 3 .

Male. Tergum X membranous, with 1 pair of long, slender dorsal processes, widely separated at base, converging distally (Fig. 5). Superior appendages short, robust, each with length about 3 times width (Fig. 3) in lateral view, length about 2.5 times width in dorsal view, slightly dilated distally (Fig. 5); pair of long, dorso-ventrally flattened (depressed) processes (mesal processes of tergum X) ventro-basal of superior appendages. Phallus simple, tube-like, distal part dorso-ventrally flattened; with pair of long, slender processes (phallic guides) arising from near bases of inferior appendages (Fig. 3). Inferior appendages longer than superior appendages, fused; in ventral view forming large, ovoid shield, truncated distally, length about twice width (Fig. 4); in lateral view slender, about 5 times longer than wide, dilated near middle (Fig. 3).

Female. Genitalia with pair of small robust obliquely truncate lobes on sternite VIII (Fig. 24).

Holotype male: Australia: Queensland, Birthday Creek, $2.5 \mathrm{~km}$ NNW Paluma, $18^{\circ} 58^{\prime} \mathrm{S}, 146^{\circ} 10^{\prime} \mathrm{E}$, at light, 17 Mar 1989, R. StClair (NMV, T-20973).

Paratypes: Queensland. 2 males, same data as for holotype; 1 male (specimen CT-419 figured), 1 female (specimen CT-418 figured), same data as for holotype, except 7 Apr 1990; 2 males, 7 females, same data as for holotype, except 17 Mar 1990; 15 males, Birthday Creek, 1857'S, 146²10'E, 795 m, light trap, 31 Oct 1993, A.L.Sheldon (NMV).

Other material examined: Queensland. 13 males, 4 females, Camp Creek tributary, Mt. Spec State Forest, 760 m, $18^{\circ} 57^{\prime} \mathrm{S}, 146^{\circ} 10^{\prime} \mathrm{E}$, light trap, 30 Oct 1993-15 Mar 1994, A.L. Sheldon; 4 males, Camp Ck proper, Mt Spec State Forest, $760 \mathrm{~m}, 1^{\circ} 57^{\prime} \mathrm{S}, 146^{\circ} 10^{\prime} \mathrm{E}$, light trap, 17 Jan 1994, A.L. Sheldon; 1 male, Yuccabine Creek, Kirrama State Forest, $18^{\circ} 12^{\prime} \mathrm{S}, 145^{\circ} 54^{\prime} \mathrm{E}$, Mar 1986, R. Pearson \& L. Benson; 2 males, same data, except Oct 1984; 3 females, Mulgrave River, W Gordonvale, 29 Apr 1979, A. Wells; 4 females, Kuranda, 18Jan 1975, N. Quick; 1 male, same data, except 21 Jan 1975; 1 male, same data, except 23 Jan 1975; 4 males, 6 females, same data, except 360 m, 30 Mar 1976, W.N.B. Quick; (NMV).

Etymology. Persona, "mask" in Latin, refers to the shape and markings on the fused inferior appendages of the male genitalia.

Distribution. Neboissomina persona has been collected from 7 localities in northeastern Queensland (latitudinal range $\left.16^{\circ} 49^{\prime}-18^{\circ} 57^{\prime} \mathrm{S}\right)$. 
Neboissomina krokale (Neboiss) comb. nov.

Figs 6-8

Ecnomina krokale Neboiss, 1979: 828, figs 7-9.-Neboiss, 1986: 154.

Diagnosis. Neboissomina krokale most closely resembles $N$. mida in possessing fused, ovoid inferior appendages, each tapered strongly in distal $1 / 4$ th to form a single point, but it is distinguished by the single central dorsal process visible subapically on the fused inferior appendage.

Description. Head, body, and wings light brown; wings similar to those of N. jardinei, new species (Fig. 2), length of each forewing: male $3.0 \mathrm{~mm}$, about 3.3 times width; length of each hind wing about 4.0 times width. Wing venation: Each forewing with forks 2, 3, 4 and 5 present; fork 2 length 1.6-1.7 times length of fork 3; fork 3 with short footstalk, length about twice length of footstalk, length of footstalk 1.7-1.9 times length of cross-vein $m$; cross-veins $r-m$ and $m$ nearly contiguous at footstalk of fork 3, $r-m$ and $m$ separated by about 0.6 times length of cross-vein $m$; fork 5 length about 1.7 times length of fork 4 . Hind wings each with forks 2,3 and 5 present; fork 2 with footstalk, length of fork 2 footstalk about twice length of cross-vein $r$-m, length of fork 2 about 1.2 times length of fork 3 .

Male. (Revised after Neboiss, 1979). Tergum X membranous, with pair of long, slender dorsal processes, widely separated at base, converging and crossing distally (Fig. 8). Superior appendages short and robust, in lateral view length about 2.5 times width (Fig. 6); in dorsal view length about 2.5 times width, slightly dilated distally (Fig. 8); pair of long, slender processes (mesal processes of tergum $\mathrm{X}$ ) ventro-basal of superior appendages. Phallus simple, tube-like, slender (Fig. 6). Inferior appendages longer than superior appendages, fused, in ventral view large, ovoid shield, tapered to rounded point distally, length about twice width (Fig. 7), in lateral view, length about 3 times width, dilated near middle, slightly upturned with single dorsal process subapically (Fig. 6).

Female. Unknown.

Material examined: Queensland. Holotype male, Fraser Island, Little Minker Lake, 18 Dec 1975, H. Burton (NMV, T-5697, specimen PT-547 figured).

Remarks. Neboissomina krokale appears to be restricted in distribution and probably is rare, as only 1 male specimen has been collected from the type locality on Fraser Island (latitude $24^{\circ} 53$ 'S). Neboiss's (1979) figures have been redrawn to allow direct comparisons and to accompany the description that is revised in light of new interpretations of Ecnomina and Neboissomina genitalic structures.

\section{Neboissomina mida sp. nov.}

Figs $9-11,25$

Diagnosis. Neboissomina mida closely resembles $N$. krokale in possessing fused, oval inferior appendages which are tapered strongly in their distal 1/4th to form a single point, but this species is distinguished by the pair of lateral processes visible subapically on the fused inferior appendages.

Description. Head, body, and wings light brown; wings similar to those of $N$. jardinei, new species (Fig. 2), length of each forewing: male 2.4-2.9 mm, female 2.4-2.8 mm, about 3.3 times width; length of each hind wing 3.4-4.1 times width. Wing venation: Each forewing with forks 2, 3, 4 and 5 present; fork 2 long, sessile, fork 2 length 2.0-2.3 times length of fork 3; fork 3 short, with long footstalk, length 0.9-1.3 times length of footstalk, footstalk of fork 3 length 2.7-3.2 times length of cross-vein $m$, cross-veins $r-m$ and $m$ nearly contiguous at fork 3, $r$ $m$ and $m$ separated by $0.4-0.7$ times length of cross-vein $m$; fork 5 long, length about 1.7 times length of fork 4 . Each hind wing with forks 2, 3 and 5 present; fork 2 with long footstalk, length of footstalk 1.4-2.4 times length of cross-vein $r$ - $m$, fork 2 length 1.3-1.7 times length of fork 3.

Male. Tergum X membranous, with 1 pair of long, slender dorsal processes, widely separated at base, converging and crossing distally (Fig. 11). Superior appendages short and robust, in lateral view length about twice width, tapered slightly in distal 1/3rd (Fig. 9), in dorsal view length about 2.5 times width, slightly dilated distally (Fig. 11); pair of long, slender processes (mesal processes of tergum $\mathrm{X}$ ) ventro-basal of superior appendages. Phallus simple, tube-like, relatively slender with spine-like process dorsally (Fig. 9). Inferior appendages longer than superior appendages, fused, in ventral view large, ovoid shield, tapered slightly in distal 1/4th to point, length about 1.8 times width (Fig. 10), in lateral view length about 5 times width, dilated near middle, narrowed distally (Fig. 9). 
Female. Genitalia without pair of obvious lobes on sternite VIII, with small mesal notch distally (Fig. 25).

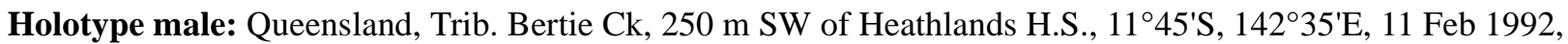
Cartwright and Wells (NMV, T-21002).

Paratypes: Queensland. 1 male, 2 females (specimen CT-502 figured), collected with holotype; 1 male (specimen CT-463 figured), Gunshot Ck, Telegraph Crossing, $11^{\circ} 44^{\prime} \mathrm{S}, 142^{\circ} 29^{\prime} \mathrm{E}, 18$ Feb 1992, Cartwright and Wells; 3

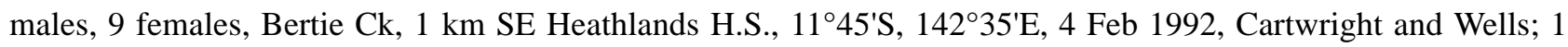
male, Cholmondeley Ck, Telegraph Crossing, $11^{\circ} 27^{\prime} \mathrm{S}, 142^{\circ} 26^{\prime} \mathrm{E}, 8-9$ Feb 1992, Cartwright and Wells (NMV).

Other material examined: Queensland. 1 male, $11 \mathrm{~km}$ ENE Mt Tozer, $12^{\circ} 42^{\prime} \mathrm{S}, 143^{\circ} 18^{\prime} \mathrm{E}, 11-16 \mathrm{Jul} 1986$, J.C. Cardale (ANIC); 1 male, Middle Claudie R., Iron Range, 29 Sep 1974, Moulds (NMV).

Etymology. Mida- Queensland Aboriginal word for "shield," referring to the shape of the fused inferior appendages.

Remarks. Neboissomina mida has been collected from 6 localities in 2 areas of Cape York Peninsula, northern Queensland (latitudinal range $11^{\circ} 27^{\prime}-12^{\circ} 44^{\prime} \mathrm{S}$ ).

\section{Neboissomina jardinei sp. nov.}

Figs 1, 2, 12-14, 26

Diagnosis. Neboissomina jardinei is similar to N. kuranya and N. riyala in possessing inferior appendages which are fused to form a single large sub-rectangular plate, but it is distinguished by small differences in the inferior appendages, in ventral view with a small central notch distally, and in lateral view sub quadrate, truncate distally.

Description. Head, body, and wings light brown, abdomen paler ventrally; wings typical for the genus (Fig. 2), length of each forewing: male 2.3-2.5 mm, female 2.4-2.8 mm; length 2.9-3.1 times width; length of each hind wing 3.2-3.3 times width. Wing venation: Each forewing with forks 2, 3, 4 and 5 present; fork 2 long, sessile, length 1.5-1.7 times length of fork 3; fork 3 with long footstalk, fork 3 length 1.6-1.7 times length of footstalk, length of footstalk 2.3-2.6 times length of cross-vein $m$, cross-veins $r-m$ and $m$ nearly contiguous at fork $3, r-m$ and $m$ separated by $0.0-0.2$ times length of cross-vein $m$; fork 5 long, length about 1.7 times length of fork 4 . Hind wings each with forks 2,3 and fork 5 present; fork 2 with short footstalk, length of footstalk 0.4-1.3 times length of cross-vein $r$ - $m$, fork 2 length 1.2-1.6 times length of fork 3.

Male. Tergum X membranous, with 1 pair of long, slender dorsal processes, widely separated at base, converging near middle, and diverging slightly distally (Fig. 14). Superior appendages short and robust, in lateral view length about twice width (Fig. 12), in dorsal view length about twice width, slightly dilated distally (Fig. 14); pair of long, dorso-ventrally flattened (depressed) processes (mesal processes of tergum X) ventro-basal of superior appendages. Phallus simple, tube-like; with pair of long, slender processes (phallic guides) arising from near base of inferior appendages (Fig. 12). Inferior appendages longer than superior appendages, fused, in ventral view large, sub-rectangular shield, truncate distally, length about 1.4 times width (Fig. 13), in lateral view sub-rectangular, length about 3 times width, truncate distally (Fig. 12).

Female. Genitalia with pair of robust obliquely truncate lobes on sternite VIII; segment X robust (Fig. 26).

Holotype male: Queensland, Canal Ck u/s jn Eliot Ck, $11^{\circ} 23^{\prime} \mathrm{S}, 142^{\circ} 25^{\prime} \mathrm{E}, 6$ Feb 1992, Cartwright and Wells (NMV, T-21020).

Paratypes: Queensland. 20 males (specimen CT-424 figured), 20 females (specimen CT-425 figured), collected with holotype (NMV).

Other material examined: Queensland. 8 males, 40 females, collected with holotype; 41 males, 25 females, Eliot Ck u/s jn Canal Ck, 11 ${ }^{\circ} 23^{\prime} \mathrm{S}, 142^{\circ} 25^{\prime} \mathrm{E}, 6$ Feb 1992, Cartwright and Wells; 5 males, 21 females, Dulhunty R., Telegraph Crossing, $11^{\circ} 50^{\prime} \mathrm{S}, 142^{\circ} 30^{\prime} \mathrm{E}, 8^{-9}$ Feb 1992, Cartwright and Wells; 2 males, 20 females, same loc. and coll., 10 Feb 1992 (NMV).

Etymology. Jardinei- named after Douglas Jardine (North Queensland explorer).

Remarks. Many specimens of Neboissomina jardinei have been collected from 3 localities on Cape York Peninsula, northern Queensland (latitudinal range $11^{\circ} 23^{\prime}-11^{\circ} 50^{\prime} \mathrm{S}$ ). 
Diagnosis. Neboissomina kuranya is most similar to N. riyala in possessing inferior appendages which are fused to form a single large sub-rectangular plate, but it is distinguished by small differences in the inferior appendages, in ventral view with a single small central rounded process distally, in lateral view sub-triangular, length about 3 times width.

Description. Head, body, and wings light brown, abdomen paler ventrally; wings similar to those of $N$. jardinei (Fig. 2), length of each forewing: male $3.0 \mathrm{~mm}$, female $3.1 \mathrm{~mm}$; length about 3.0 times width; length of each hind wing 3.2-3.3 times width. Wing venation: Each forewing with forks 2, 3, 4 and 5 present; fork 2 sessile, length 1.3-1.4 times length of fork 3; fork 3 with short footstalk, length of fork about 3.8 times length of footstalk, length of footstalk of fork 3 about same length as cross-vein $m$, cross-veins $r-m$ and $m$ nearly contiguous at fork $3, r-m$ and $m$ separated by $0.4-0.6$ times length of cross-vein $m$; length of fork 5 about 1.7 times length of fork 4 . Hind wings each with forks 2,3 and 5 present; fork 2 sessile or with very short footstalk, when fookstalk of fork 2 present its length about 0.2 times length of cross-vein $r-m$, fork 2 length 1.3-1.4 times length of fork 3 .

Male. Tergum X membranous, with 1 pair of long, slender dorsal processes, widely separated (Fig. 17). Superior appendages short and robust, in lateral view broad-based, slightly tapered distally, each with length about 2.5 times width (Fig. 15), in dorsal view length about 3 times width (Fig. 17); pair of long, slender processes (mesal processes of tergum X) at base of superior appendages. Phallus simple, tube-like, slender; with pair of long, slender processes (phallic guides) arising from near base of inferior appendages (Fig. 15). Inferior appendages slightly longer than superior appendages, fused, in ventral view large, sub-rectangular shield, truncate with single small central process distally, length about 1.3 times width (Fig. 16), in lateral view broad-based, slightly tapered distally, length about 3 times width (Fig. 15).

Female. Genitalia with pair of small oblong lobes on sternite VIII, widely separated (Fig. 27).

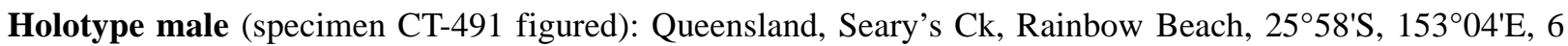
Dec 1984, G. Theischinger (NMV, T-21061).

Paratype: Queensland. 1 female (specimen CT-492 figured), collected with holotype (NMV).

Etymology. Kuranya- Australian Aboriginal word for "rainbow," referring to the type locality- Rainbow Beach.

Remarks. Only 2 specimens of Neboissomina kuranya have been collected from the type locality in southeastern Queensland (latitude 2558'S).

\section{Neboissomina riyala sp. nov.}

Figs 18-20, 28

Diagnosis. Neboissomina riyala is most similar to $N$. philsuteri and $N$. kuranya in possessing inferior appendages which are fused to form a single large sub-rectangular plate, but it is distinguished by small differences in the inferior appendages, in ventral view without a single small central process distally, in lateral view narrowed subapically, length about 4.5 times width.

Description. Head, body, and wings light brown, abdomen paler ventrally; wings similar to those of $N$. jardinei (Fig. 2), length of each forewing: male 2.3-3.1 mm, female 2.8-3.1 mm, length about 3.0 times width; length of each hind wing 3.2-3.3 times width. Wing venation: Each forewing with forks 2, 3, 4 and 5 present; fork 2 sessile, length about 1.3-1.4 times length of fork 3; fork 3 with short footstalk, length of fork about 3.8 times length of footstalk, length of footstalk of fork 3 about same length as cross-vein $m$, cross-veins $r-m$ and $m$ nearly contiguous at fork 3, $r-m$ and $m$ separated by 0.4-0.6 times length of cross-vein $m$; length of fork 5 about 1.7 times length of fork 4 . Hind wings each with forks 2,3 and 5 present; fork 2 sessile or with very short footstalk, footstalk of fork 2 length 0.0-0.2 times length of cross-vein $r-m$, fork 2 length 1.3-1.4 times length of fork 3 .

Male. Tergum X membranous, with pair of long, slender dorsal processes, converging and crossing near middle (Fig. 20). Superior appendages short and robust, in lateral view broad-based, slightly tapered distally, length about 2.5 times width (Fig. 18), in dorsal view length about 3 times width, slightly dilated distally (Fig. 20); pair of long, slender processes (mesal processes of tergum X) ventro-basal of superior appendages. Phallus simple, tubelike, (Fig. 18). Inferior appendages slightly longer than superior appendages, fused, in ventral view large, sub-rect- 
angular shield, truncate distally, length about 1.5 times width (Fig. 19), in lateral view broad-based, slightly tapered distally, narrowed subapically, dilated apically, length about 4.5 times width (Fig. 18).

Female. Genitalia with pair of small sub-quadrate lobes on sternite VIII, widely separated (Fig. 28).

Holotype male: Northern Territory, ARRS Radon Springs, $12^{\circ} 45^{\prime}$ S, $132^{\circ} 55^{\prime}$ E, lt tr., $13-14$ Apr 1988, P. Suter and A. Wells (NMV, T-21063).

Paratypes: Northern Territory. 7 males, collected with holotype; 2 males, same loc. and coll., $1 \mathrm{hr}$ before dawn, 14 Apr 1988; 2 males, same loc. and coll., 6V lt tr., dawn, 14 Apr 1988; 1 male (specimen CT-470 figured), 1 female (specimen CT-492 figured), Jim Jim Falls campsite, Kakadu Nat. Pk, 13²16'S, 13249'E, 13 Aug 1996, I. Edwards (NMV).

Other material examined: Northern Territory. 1 male, 2 females, Adelaide R., $15 \mathrm{~km}$ E of Stuart Hwy, 15 Aug 1979, J. Blyth; 2 males, ARRS Bowerbird Billabong outlet, 1247'S, 13302'E, 1 Oct 1988, P. Dostine; 1 male, ARRS Baroalba Springs, 22 May 1988, A. Wells and P. Suter; 1 male, Nourlangie camp lagoon, Kakadu N.P., 4 Sep 1979, J. Blyth; 3 males, 1 female, Rock Hole Ck, lt tr., Nov 1988, P. Dostine; 6 males, 13 females, S Alligator R., UDP Falls, 7 Sep 1979, J. Blyth; 1 male, ARRS Kambolgie Ck, 6V lt tr., 25-26 May 1988, P. Suter and A. Wells; 1 male, S Alligator R. nr Koolpin Crossing, 14 Oct 1987, P. Dostine; 7 males, 11 females, ARRS ck $5 \mathrm{~km} \mathrm{~W}$ of OSS field station, $13^{\circ}$ ?, 132 $34^{\prime} \mathrm{E}, 19$ Apr 1988, A. Wells and P. Suter; 4 males, 2 females, ARRS S Alligator R. at Gimbat OSS Stn, 28 Apr 1988, P. Dostine; 1 male, same loc., 6V lt tr., 24-25 may 1988, P. Suter and A. Wells; 5 males, 7 females, Butterfly Gorge, Katherine Gorge N.P., 27 Jan 1977, M.S. and B.J. Moulds; 1 male, Amagule Pool, Groote Eylandt, MV lt, 6 Feb 1984, M. Davies.

Etymology. Riyala- Northern Territory Aboriginal word for "springs, streams, and rivers," referring to the typical habitat.

Remarks. Neboissomina riyala is a relatively common and widespread species having been collected from about 13 localities across the northern Northern Territory (latitudinal range $12^{\circ} 45^{\prime}-14^{\circ} 19^{\prime} \mathrm{S}$ ).

\section{Neboissomina philsuteri sp. nov.}

Figs 21-23

Diagnosis. Neboissomina philsuteri is most similar to N. riyala in possessing inferior appendages which are fused to form a single large sub-rectangular plate, but it is distinguished by small differences in the inferior appendages, in lateral view not narrowed subapically, with a pair of small disto-lateral projections, in ventral view narrowed in basal $1 / 3$.

Description. Head, body, and wings light brown, abdomen paler ventrally; wings similar to those of $N$. jardinei (Fig. 2), length of each forewing: male $3.0 \mathrm{~mm}$, about 3.0 times width; length of each hind wing 3.2-3.3 times width. Wing venation: Each forewing with forks 2, 3, 4 and 5 present; fork 2 sessile, length 1.3-1.4 times length of fork 3 ; fork 3 with short footstalk, length of fork about 3.8 times length of footstalk, length of footstalk of fork 3 about same length as cross-vein $m$, cross-veins $r-m$ and $m$ nearly contiguous at fork 3, $r-m$ and $m$ separated by 0.4 0.6 times length of cross-vein $m$; length of fork 5 about 1.7 times length of fork 4 . Hind wings each with forks 2,3 and 5 present; fork 2 sessile or with very short footstalk, when present footstalk of fork 2 about 0.2 times length of cross-vein r-m, fork 2 length 1.3-1.4 times length of fork 3.

Male. Tergum X membranous, with pair of long, slender dorsal processes, narrowly separated (Fig. 23). Superior appendages short and robust, in lateral view broad-based, slightly tapered distally, each with length about twice width (Fig. 21), in dorsal view, length about twice width, slightly dilated distally (Fig. 23); pair of long, slender processes (mesal processes of tergum X) ventro-basal of superior appendages. Phallus simple, tube-like, robust (Fig. 21). Inferior appendages slightly longer than superior appendages, fused, in ventral view large, sub-rectangular shield, truncate with shallow central notch distally, length about 1.5 times width, narrowed slightly in basal 1/ 3rd (Fig. 22), in lateral view length about 3.7 times width, with pair of small disto-lateral projections (Fig. 21).

Female. Unknown.

Holotype male (specimen CT-519 figured): Western Australia, Camp Ck, Mitchell Plateau, $14^{\circ} 50^{\prime} \mathrm{S}, 125^{\circ} 50^{\prime} \mathrm{E}$, 13 Jul 1978, P. Suter (NMV, T-21077).

Etymology. Philsuteri- named for the collector, Dr Phil Suter.

Remarks. Only 1 specimen of Neboissomina philsuteri has been collected from the type locality in northern Western Australia (latitude $14^{\circ} 50^{\prime} \mathrm{S}$ ). 

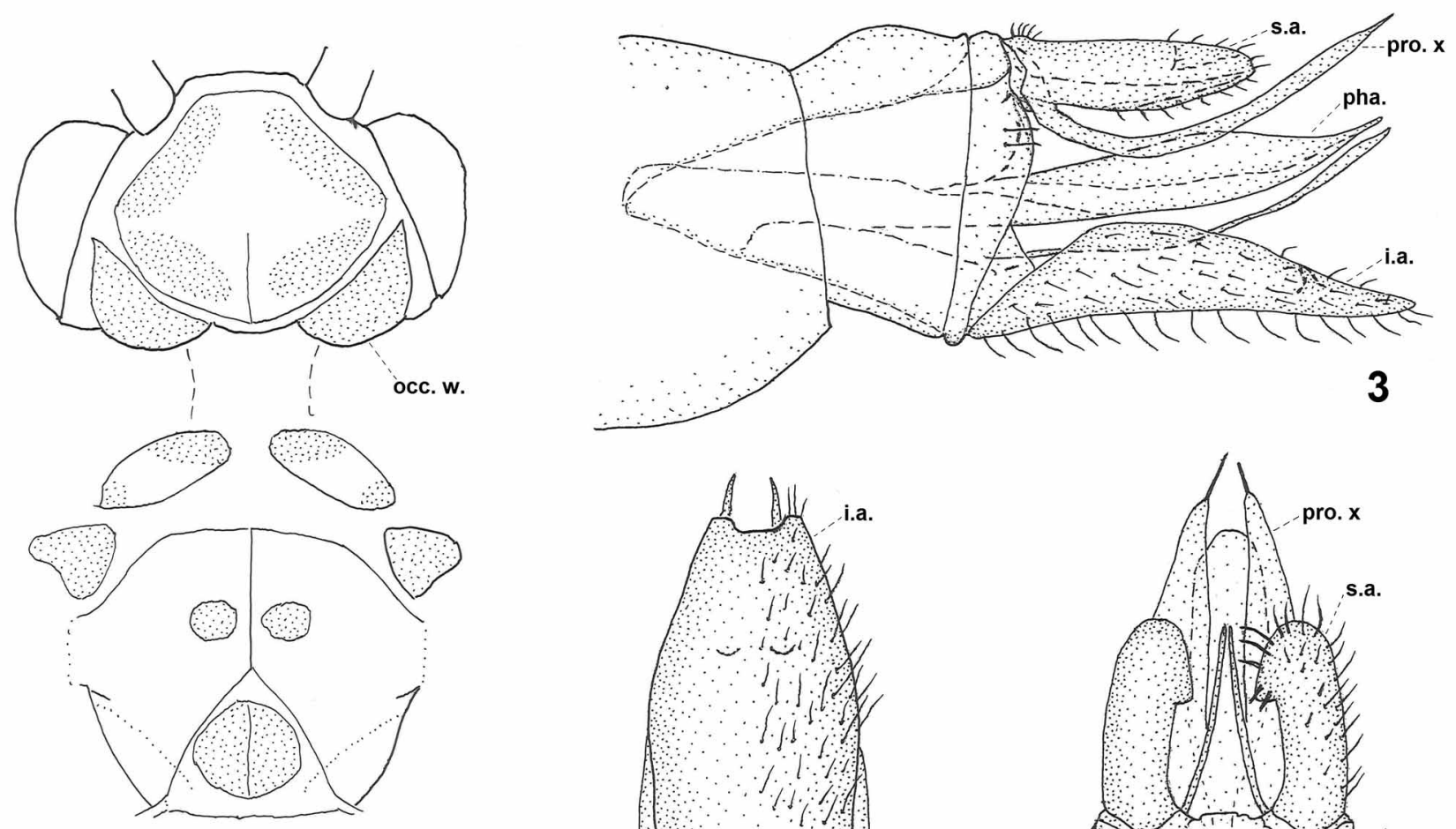

4
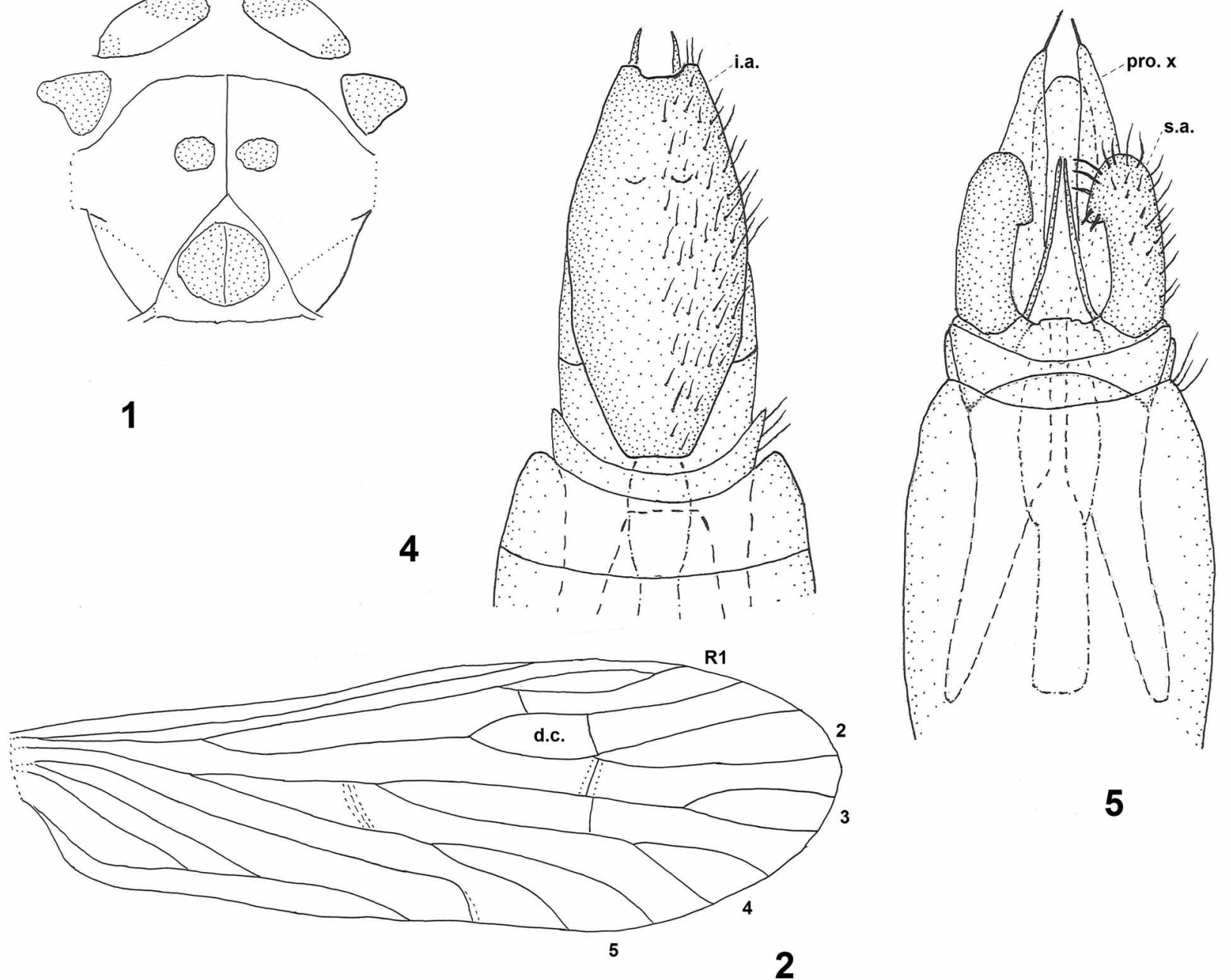

5

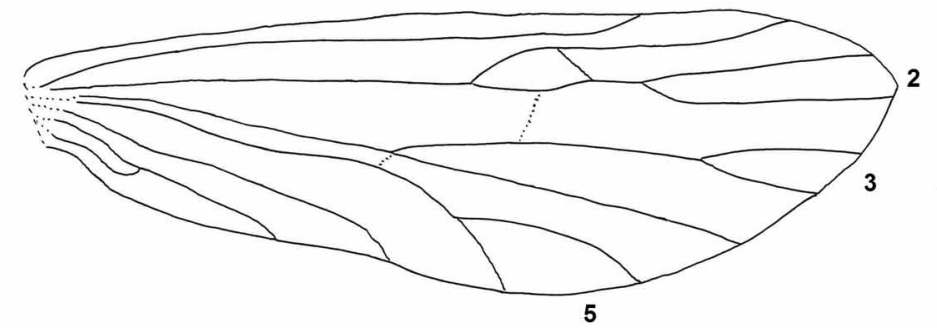

FIGURES 1-5. Neboissomina spp. 1-2, Neboissomina jardinei, new species: 1, head and thorax, dorsal view; 2, right forewing and hind wing, dorsal view. 3-5, Neboissomina persona, new species, male genitalia: 3: left lateral view; 4, ventral view; 5, dorsal view. i.a. $=$ inferior appendages; pha. $=$ phallus; pro. $\mathrm{X}=$ mesal processes of tergum $\mathrm{X}$; s.a. $=$ superior appendages. 


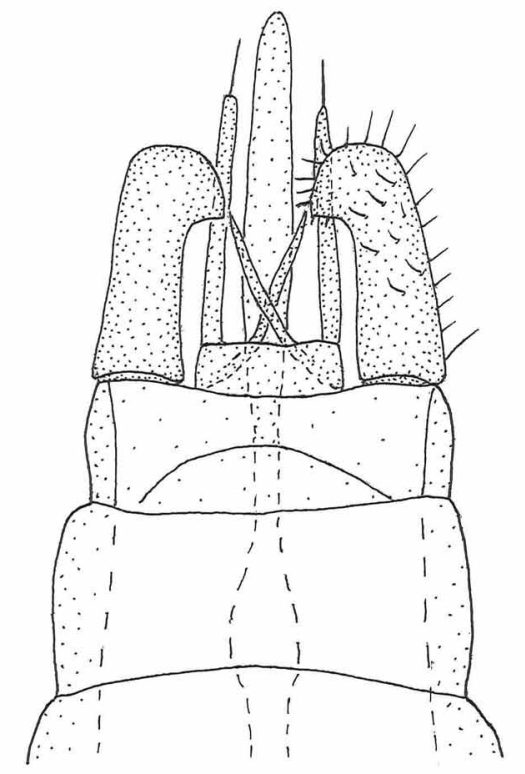

11

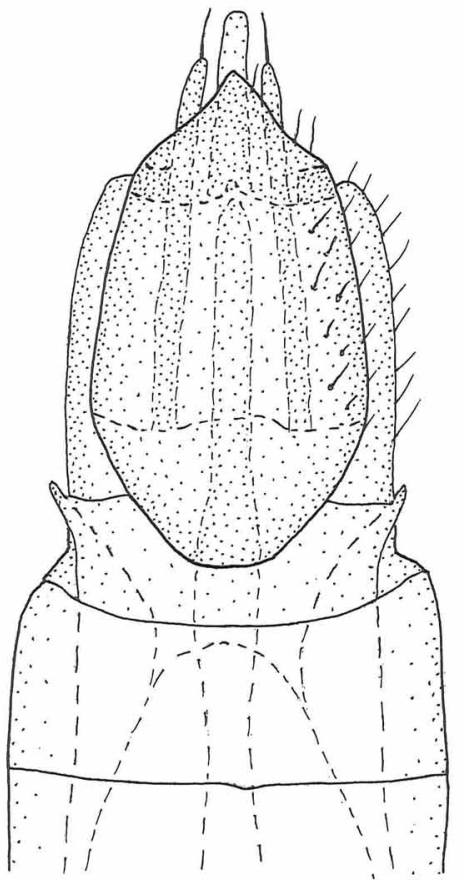

10

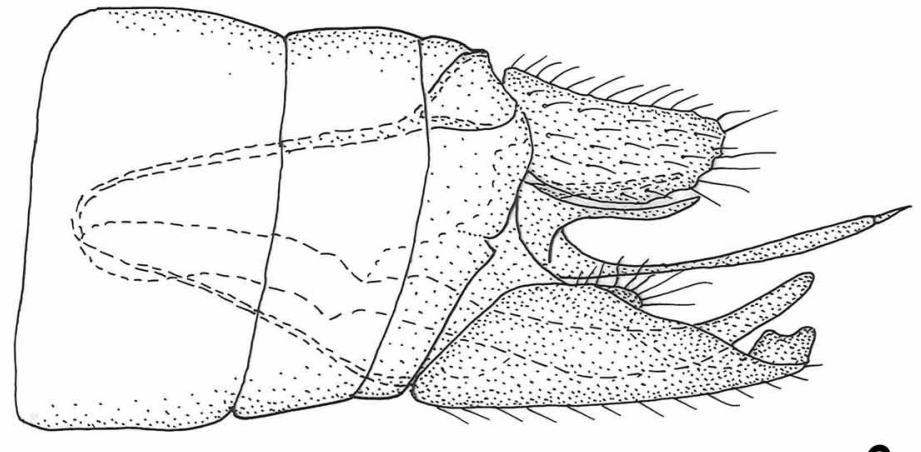

6
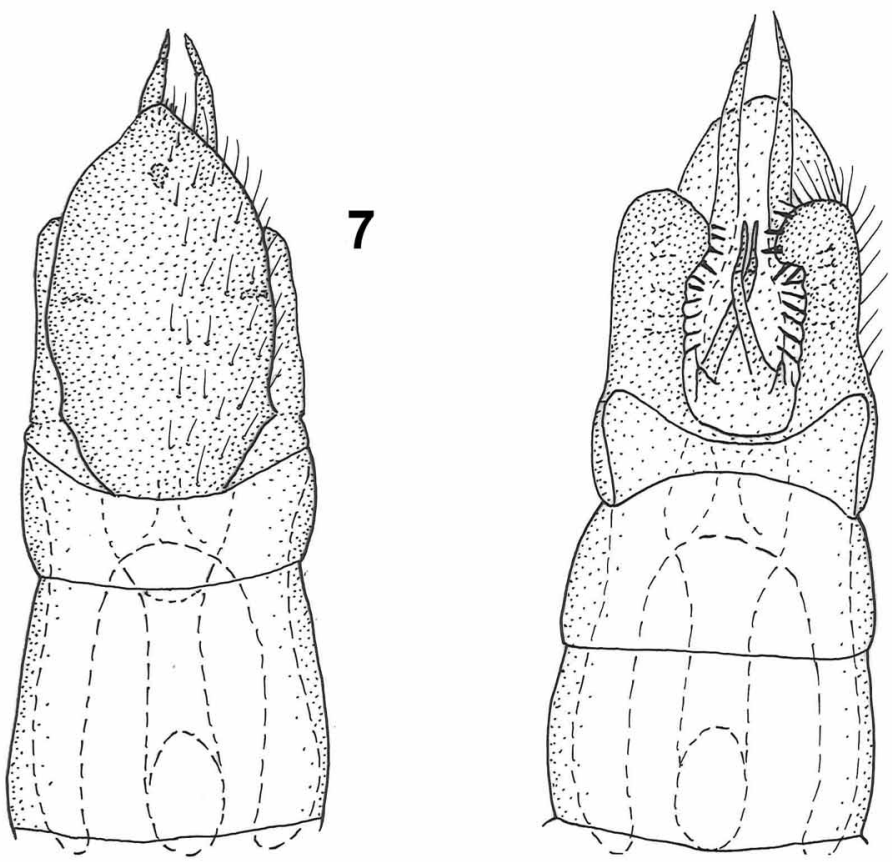

8

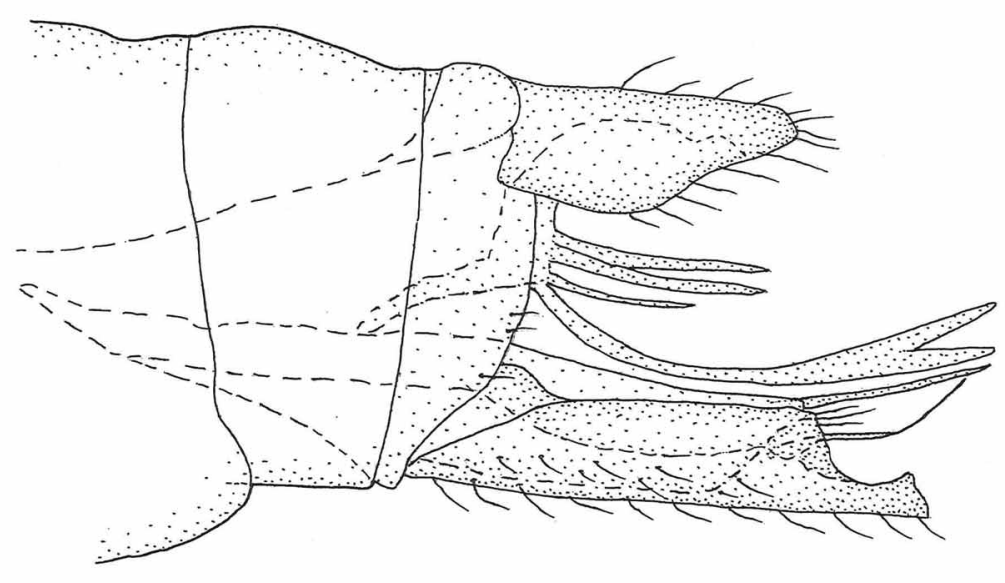

9

FIGURES 6-11. Neboissomina spp. male genitalia. 6-8, Neboissomina krokale (Neboiss): 6, left lateral view; 7, ventral view; 8, dorsal view. 9-11, Neboissomina mida, new species: 9, left lateral view; 10, ventral view; 11, dorsal view. 


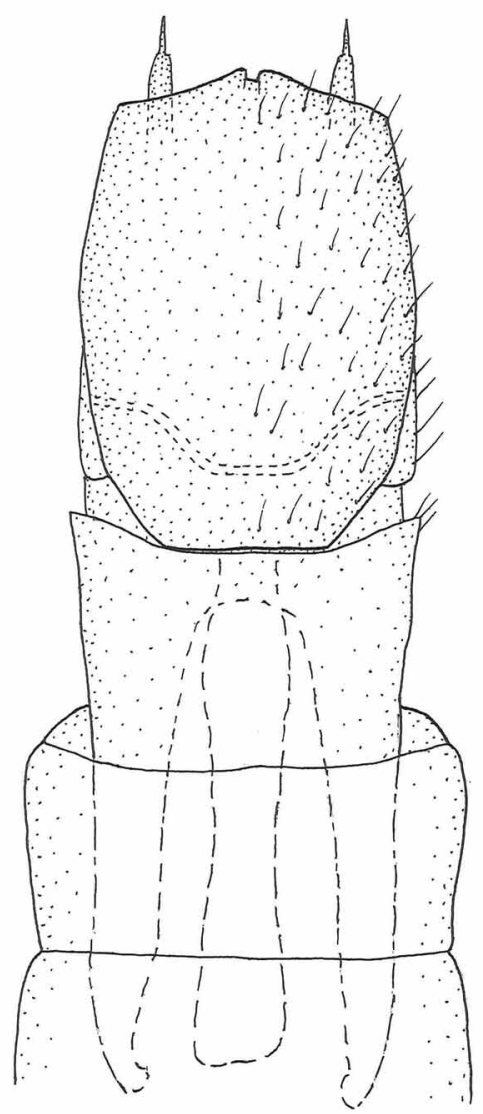

13

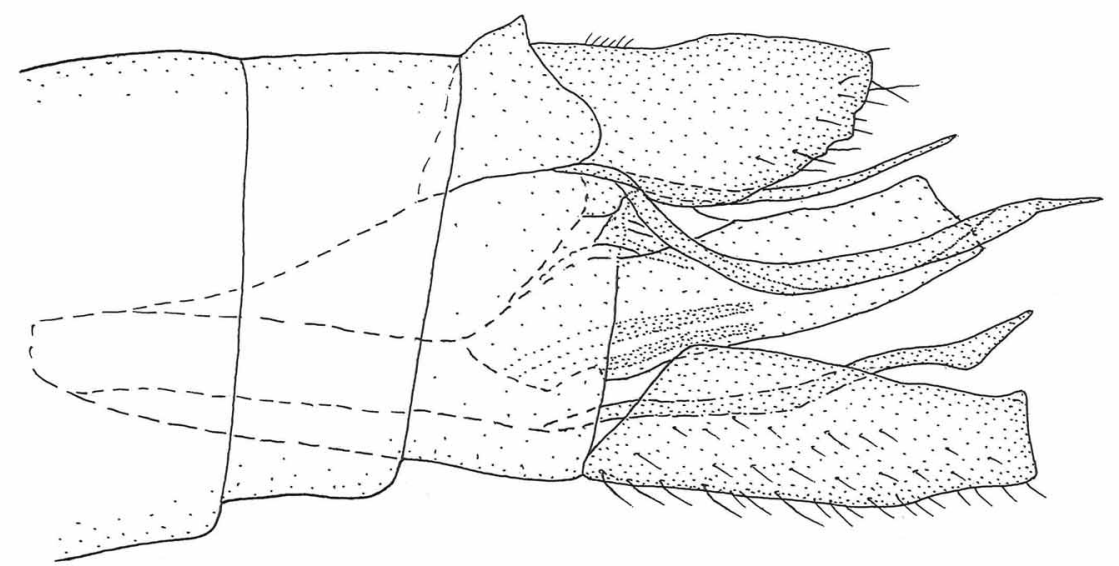

12
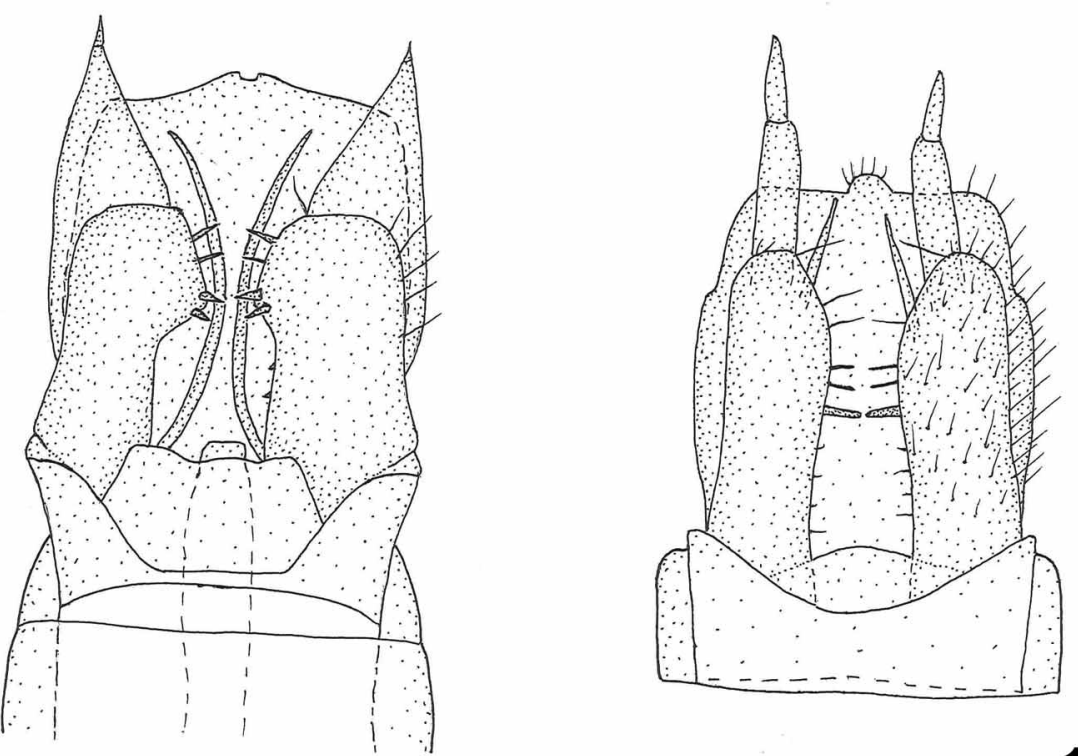

17

\section{4}

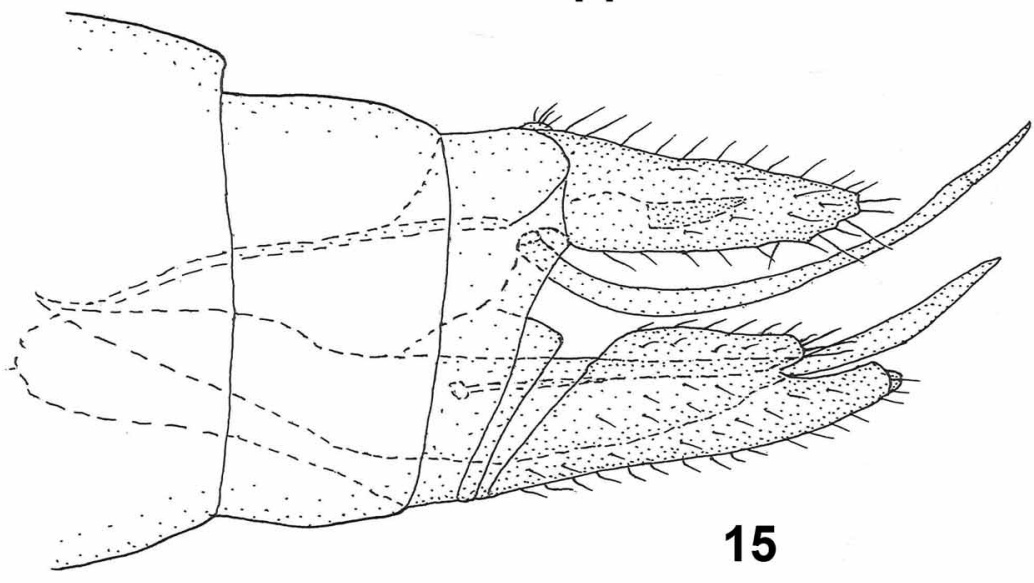

16

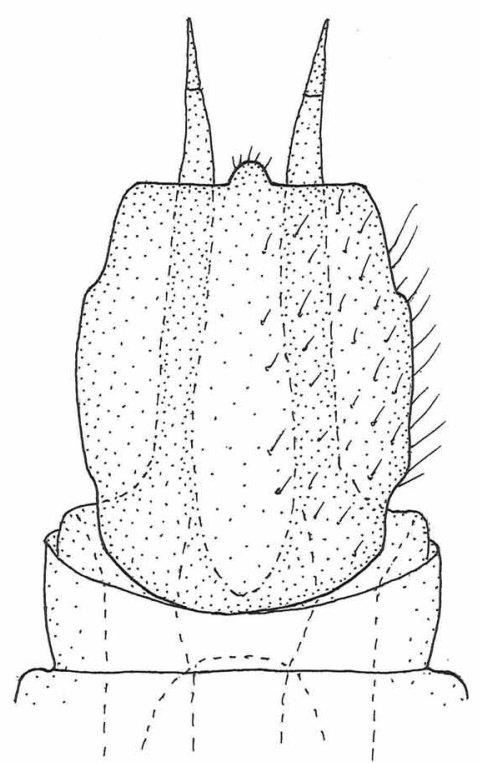

FIGURES 12-17. Neboissomina spp. male genitalia. 12-14, Neboissomina jardinei, new species: 12, left lateral view; 13, ventral view; 14, dorsal view. 15-17, Neboissomina kuranya, new species: 15, left lateral view; 16, ventral view; 17, dorsal view. 

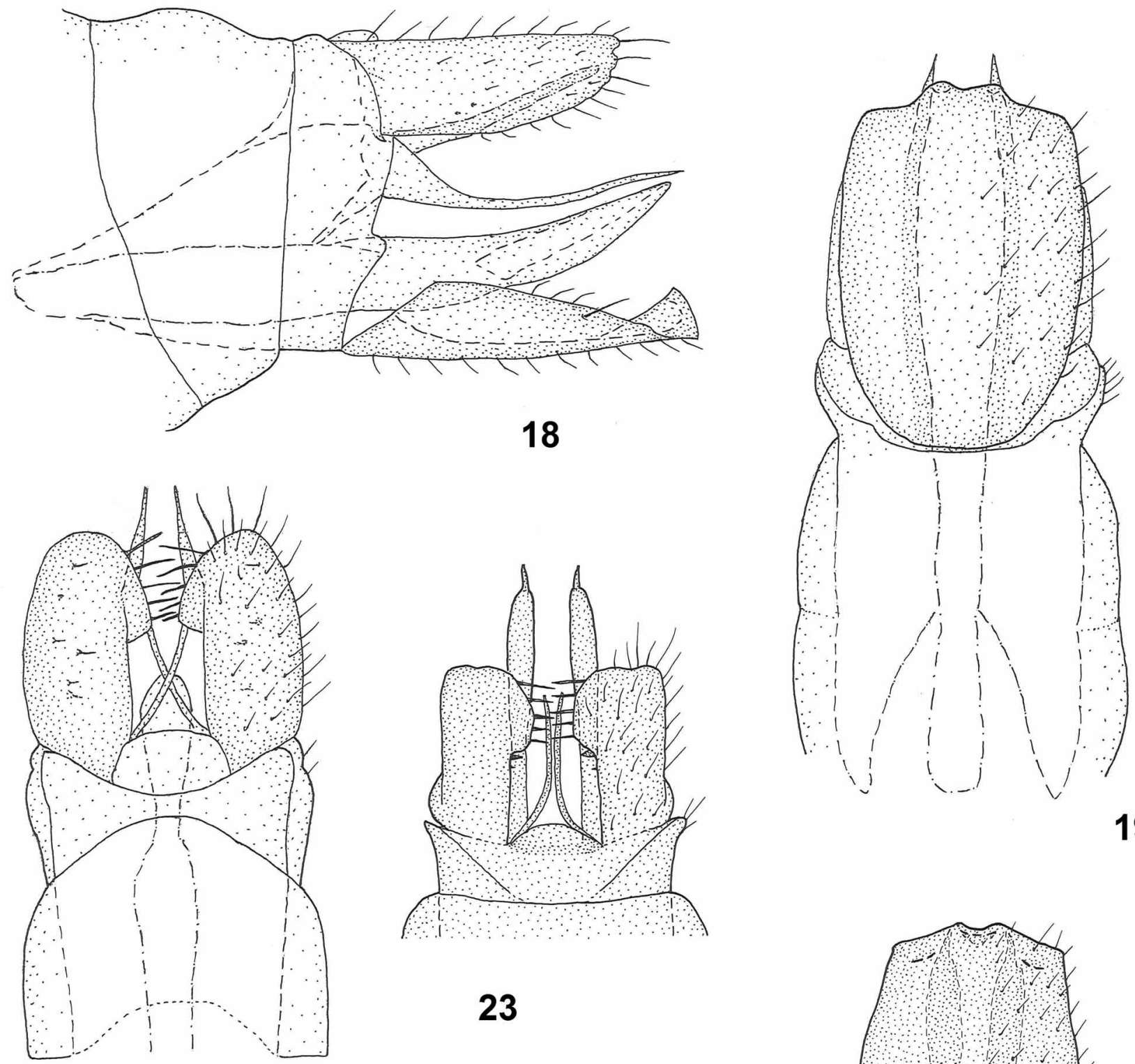

19

20
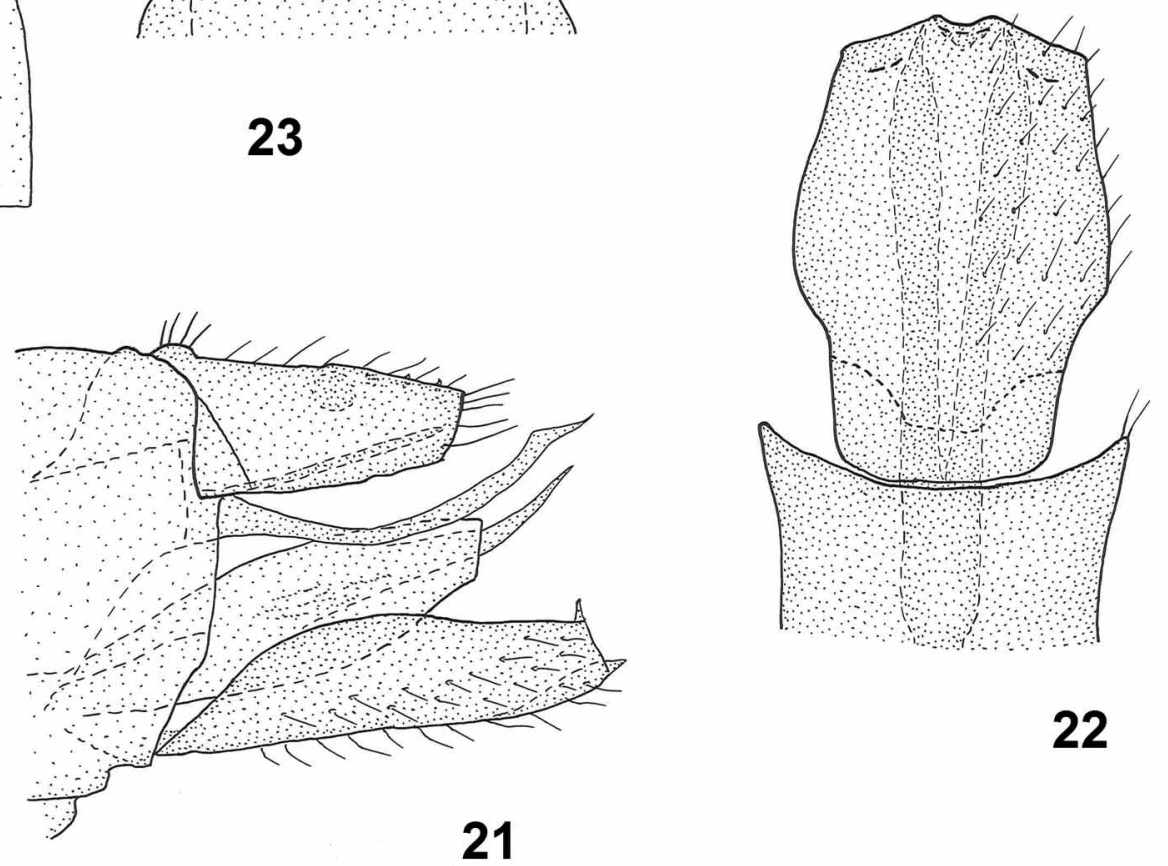

22

FIGURES 18-26. Neboissomina spp. male genitalia. 18-20, Neboissomina riyala, new species: 18, left lateral view; 19, ventral view; 20, dorsal view. 21-23, Neboissomina philsuteri, new species: 21, left lateral view; 22, ventral view; 23, dorsal view. 


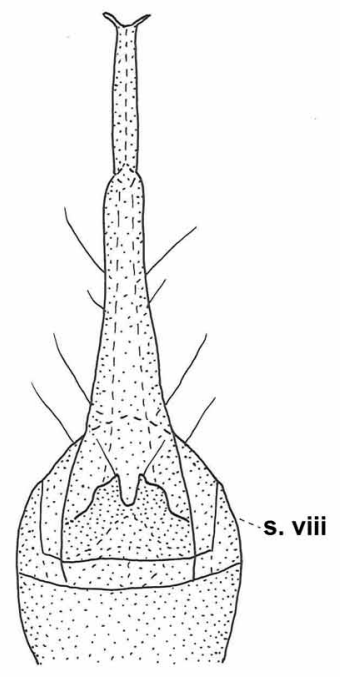

24

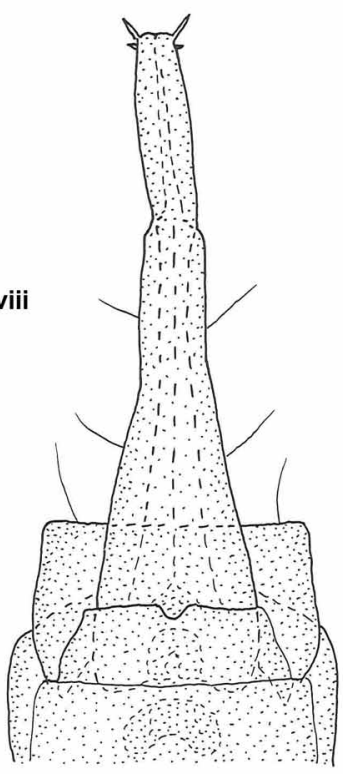

25

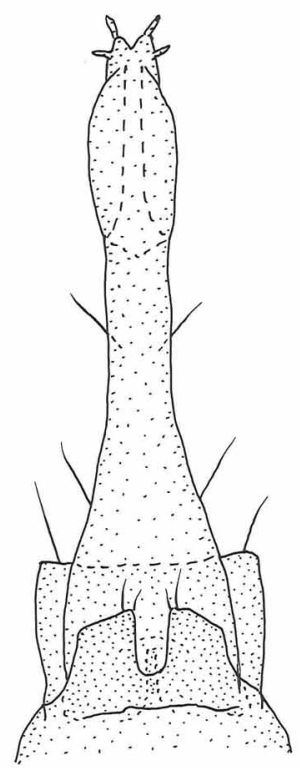

26

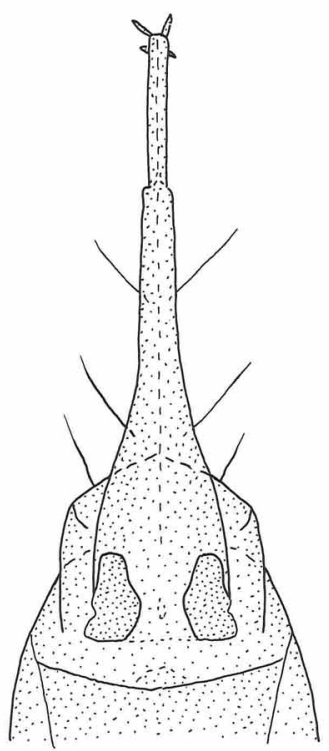

27

FIGURES 24-28. Neboissomina spp. female genitalia in ventral view. 24, Neboissomina persona, new species. 25, Neboissomina mida, new species. 26, Neboissomina jardinei, new species. 27, Neboissomina kuranya, new species. 28, Neboissomina riyala, new species. s.viii $=$ sternite viii.

\section{Acknowledgements}

I thank the Department of the Environment and Water Resources, in particular Australian Biological Resources Study (ABRS) for providing a grant to undertake this work, Drs Arturs Neboiss (NMV) and Alice Wells (ANIC) for providing access to the specimens and, together with John Dean, referees and editors, for helpful advice and constructive comments on earlier drafts of this manuscript. Finally, I am grateful to John Dean and Dr Ros St Clair for technical help with scanning the figures and moral support during the project.

\section{References}

Cartwright, D.I. (1990) The Australian species of Ecnomus McLachlan (Trichoptera: Ecnomidae). Memoirs of the Museum of Victoria, 51, 1-48.

Cartwright, D.I. (1997) Preliminary guide to the identification of late instar larvae of Australian Ecnomidae, Philopotamidae and Tasimiidae (Insecta: Trichoptera). Identification guide no. 10. Co-operative Research Centre for Freshwater Ecology, Albury. 33 pp.

Cartwright, D.I. (2008) A review of the Australian species of Ecnomina Kimmins and Daternomina Neboiss (Trichoptera: Ecnomidae). Zootaxa, 1774, 1-76.

Cartwright, D.I. (2009) Austrotinodes Schmid, a South and Central American caddisfly genus, newly recorded in Australia, with the description of new species (Trichoptera: Ecnomidae). Zootaxa, 2142, 1-19.

Cartwright, D.I. (2010) Descriptions of 2 new genera and 13 new species of caddisflies from Australia (Trichoptera: Ecnomi- 
dae). Zootaxa, 2415, 1-21.

Johanson, K.A. \& Espeland, M. (2009) Phylogeny of the Ecnomidae (Insecta: Trichoptera). Cladistics, 25, 1-13.

Li, Y.J. \& Morse, J.C. (1997) Species of the genus Ecnomus (Trichoptera: Ecnomidae) from the People's Republic of China. Transactions of the American Entomological Society, 123, 85-134.

Neboiss, A. (1977) A taxonomic and zoogeographic study of Tasmanian caddis-flies (Insects: Trichoptera). Memoirs of the National Museum of Victoria, 38, 1-208.

Neboiss, A. (1979) A review of caddis-flies from three coastal islands of south-eastern Queensland (Insecta: Trichoptera). Australian Journal of Marine and Freshwater Research, 29 (1978), 825-843 (publ. 18 Jan 1979).

Neboiss, A. (1982) The caddis-flies (Trichoptera) of south-western Australia. Australian Journal of Zoology, 30, $271-325$.

Neboiss, A. (1986) Atlas of Trichoptera of the SW Pacific-Australian Region. Dr W. Junk, Dordrecht. 286 pp.

Neboiss, A. (2003) New genera and species, and new records, of Tasmanian Trichoptera (Insecta) Papers and Proceedings of the Royal Society of Tasmania, 136, 43-82.

Walker, K., Neboiss, A., Dean, J. \& Cartwright, D. (1995) A preliminary investigation of the caddis-flies (Insecta: Trichoptera) of the Queensland wet tropics. Australian Entomologist, 22, 19-31.

Ward, J.B. \& Schefter, P.W. (2000) A new genus and twenty new species of New Caledonian Ecnomidae (Trichoptera). Records of the Canterbury Museum, 14, 55-87.

Wells, A. (1991) A guide to the caddisflies (Trichoptera) of the Alligator Rivers Region, Northern Territory. Open File Record, Supervising Scientist for the Alligator Rivers Region. 105 pp.

Wells, A. \& Cartwright, D.I. (1993) Trichoptera, Ephemeroptera, Plecoptera and Odonata of the Jardine River area, Cape York, northern Queensland. Cape York Peninsula Scientific Expedition Wet Season 1992. Report vol. 2, The Royal Geographical Society of Queensland, Inc., pp 221-230. 